J. Lake Sci. (湖泊科学) , 2013, 25(6): 827-835

http: //www. jlakes. org. E-mail : jlakes@niglas.ac.cn

(C) 2013 by Journal of Lake Sciences

\title{
天目湖流域丘陵山区典型土地利用类型氮流失特征"
}

\author{
聂小飞 ${ }^{1,2}$, 李恒鹏 ${ }^{1 * *}$, 黄群彬 $^{1,2}$, 习亚芹 ${ }^{1,2}$, , 姜加虎 $^{1}$ \\ ( 1 : 中国科学院南京地理与湖泊研究湖泊与环境国家重点实验室, 南京 210008) \\ (2: 中国科学院大学,北京 100049 )
}

\begin{abstract}
摘 要: 天目湖丘陵山区农业综合开发持续推进, 大量林地转变为茶园, 迫切需要认识茶园扩张对流域氮流失的影响. 本 研究选取茶园、次生马尾松林和毛竹林开展自然降雨条件下的径流小区实验, 分析天目湖丘陵山区典型用地类型径流氮 流失规律, 为评估丘陵山区综合开发的水环境影响提供实测参数. 研究表明: 茶园、次生马尾松林和毛竹林地表径流 TN 浓度分别为 $11.25 、 2.83$ 和 $3.60 \mathrm{mg} / \mathrm{L}$, 均以溶解态为主; 壤中流 TN 浓度分别为 $27.16 、 3.59$ 和 $1.06 \mathrm{mg} / \mathrm{L}$, 茶园和次生马尾 松林均以溶解性无机氮 (尤其是硝态氮) 为主,毛竹林以溶解性有机氮为主; 茶园、次生马尾松林和毛竹林的小区尺度地表径 流系数均不到 0.03 , 壤中流是丘陵山区径流的主要来源; 茶园开发加剧了丘陵山区的氮素流失, 茶园径流 $\mathrm{TN}$ 流失强度高达 $103.08 \mathrm{~kg} /\left(\mathrm{hm}^{2} \cdot \mathrm{a}\right)$, 分别是次生马尾松林和毛竹林的 7.6 和 23.2 倍,壤中流贡献了流失总量的 $86.7 \% \sim 99.7 \%$. 防治 茶园径流氮流失需重点关注壤中流输出, 在减量施肥的基础上, 采取坡脚构建毛竹林生态缓冲带/在小流域出口布设塘 坝等原位拦截措施, 实现流域氮流失综合防控.
\end{abstract}

关键词: 天目湖流域;茶园;次生马尾松林;毛竹林;氮;地表径流;壤中流;丘陵山区

\section{Characteristics of nitrogen loss via runoff from typical land uses in hilly area of Tianmuhu Reservoir watershed}

\author{
NIE Xiaofei ${ }^{1,2}$, LI Hengpeng ${ }^{1}$, HUANG Qunbin ${ }^{1,2}$, Diao Yaqin ${ }^{1,2}$ \& JIANG Jiahu ${ }^{1}$ \\ (1: State Key Laboratory of Lake Science and Environment, Nanjing Institute of Geography and Limnology, Chinese Academy of \\ Sciences, Nanjing 210008 , P. R. China) \\ (2: University of Chinese Academy of Sciences, Beijing 100049,P. R. China)
}

\begin{abstract}
A large number of forests have been shifting into tea plantation with the continuously promoting of agricultural comprehensive development in the hilly area of Tianmuhu Reservoir watershed, so it is urgent to know how tea plantation expansion influence nitrogen loss. Three experimental natural plots were delineated on tea plantation, secondary pine forest and bamboo forest to study nitrogen loss characteristics via runoff from typical land uses in hilly area of Taihuhu upstream watershed, so as to achieve measured parameters of nitrogen loss via runoff for evaluating the water environmental impact of agricultural comprehensive development in hilly area. TN concentrations in surface runoff of tea plantation, secondary pine forest and bamboo forest were 11.25, 2.83 and $3.60 \mathrm{mg} / \mathrm{L}$, respectively, mainly in dissolved form. As to subsurface runoff, they were $27.16,3.59 \mathrm{and} 1.06 \mathrm{mg} / \mathrm{L}$, respectively, and were mainly made up of DIN for tea plantation and secondary pine forest, especially as nitrate, while DON for bamboo forest. The plot scale surface runoff coefficients of tea plantation, secondary pine forest and bamboo forest were all less than 0.03 , so that subsurface runoff was the major source of runoff. Nitrogen loss was raised heavily with the expansion of tea plantation. The loss rate was $103.08 \mathrm{~kg} \mathrm{~N} /(\mathrm{ha} \cdot \mathrm{a})$, which was 7.6 and 23.2 times the loss rate of secondary pine forest and bamboo forest, and $86.7 \%-99.7 \%$ of the total load was lost via subsurface runoff. Subsurface runoff should be paid attention to on prevention and control the nitrogen loss via runoff of tea plantations, and besides reducing fertilizer application, the combination of
\end{abstract}

* 国家自然科学基金项目 (41030745)、中国科学院重点部署项目 (KZZD-EW-10-04)、中国科学院南京地理与湖泊研 究所“一三五”重点布局项目 (NIGLAS2012135005)、江苏省自然科学基金项目 (SBK200920953) 和溧阳市沙河水库 管理处科研项目联合资助. 2013-04-09 收稿; 2013-04-28 收修改稿. 聂小飞,男, 1985 年生, 博士; E-mail: xfnie85@163.com.

** 通信作者;E-mail: hpli@ niglas. ac.cn. 
construction of bamboo buffers at the toe of tea plantation slopes and ponds at the outlet of drainage, so as to prevent and control nitrogen loss via runoff by intercepting nitrogen in situ, is also considerable.

Keywords: Tianmuhu Reservoir watershed; tea plantation; secondary pine forest; bamboo forest; nitrogen; surface runoff; subsurface runoff; hilly area

天目湖流域地处宜溧河上游, 是太湖流域丘陵山区的代表性地区. 近年来, 流域内丘陵山区综合开发加 速, 大量林地转变为茶果园, 在带来巨大经济效益的同时, 也对区域生态环境造成了破坏, 带来了水土流失 加剧、河湖水质下降等一系列生态环境问题 ${ }^{[-2]}$. 已有研究表明, 茶园径流氮流失剧烈 ${ }^{[34]}$, 严重污染周边水 体, 如苕溪流域 ${ }^{[5]}$ 和西湖名胜区 ${ }^{[6]}$ 茶园径流 TN 浓度分别可高达 13.36 和 $15.4 \mathrm{mg} / \mathrm{L}$, 均远超国家地表水水 质标准的 $\mathrm{V}$ 类限值 ${ }^{[7]}$. 因降雨状况、施肥情况等不同, 不同区域茶园氮流失负荷研究结果差异较大: 印度喜 马拉雅中部地区 ${ }^{[8]}$, 我国的湖南桃源 ${ }^{[9]}$ 、安徽㪘县 ${ }^{[10]}$ 、江苏武进 ${ }^{[11]}$ 、浙江杭州 ${ }^{[6]}$ 的茶园地表径流氮流失负荷 依次分别为 $3.10 \sim 14.66 、 0.20 、 1.85 \sim 2.54 、 11.69$ 和 $0.90 \mathrm{~kg} /\left(\mathrm{hm}^{2} \cdot \mathrm{a}\right)$. 日本的研究结果表明, 茶园区地下 水 $\mathrm{TN}$ 浓度可高达 $80 \mathrm{mg} / \mathrm{L}^{[12]}$; 旱地的研究也发现, 壤中流氮流失量占径流氮流失总量的 $90 \%$ 以上 ${ }^{[13]}$. 当 前, 针对茶园径流氮流失特征的研究, 未能全面量化地表径流和壤中流氮流失状况 ${ }^{[5,9-10]}$, 此外, 针对茶园与 自然林地流失差异的比较研究尚不多见 ${ }^{[8]}$, 而准确评估丘陵山区茶园扩张对流域氮流失的影响, 需要在全 面考虑地表径流和壤中流的基础上, 与原用地类型开展对比研究. 本文采用原位径流小区实验方法,选取太 湖上游丘陵山区的茶园、次生马尾松林和毛竹林, 研究自然降雨条件下不同用地类型地表径流和壤中流氮 流失特征, 为准确评估丘陵山区综合开发的水环境效应提供参数, 并为防治水环境污染提供科学依据.

\section{1 研究区与实验布设}

\section{1 研究区与实验样地}

天目湖流域总面积 $246 \mathrm{~km}^{2}$; 土地利用以林地为主, 占流域总面积的 $43 \%$, 耕地、园地 (主要是茶园)、水 体、草地和建设用地分别占流域总面积的 $23 \% 、 11 \% 、 11 \% 、 6 \%$ 和 6\%（图 1); 地带性土壤为黄棕壤. 属于北

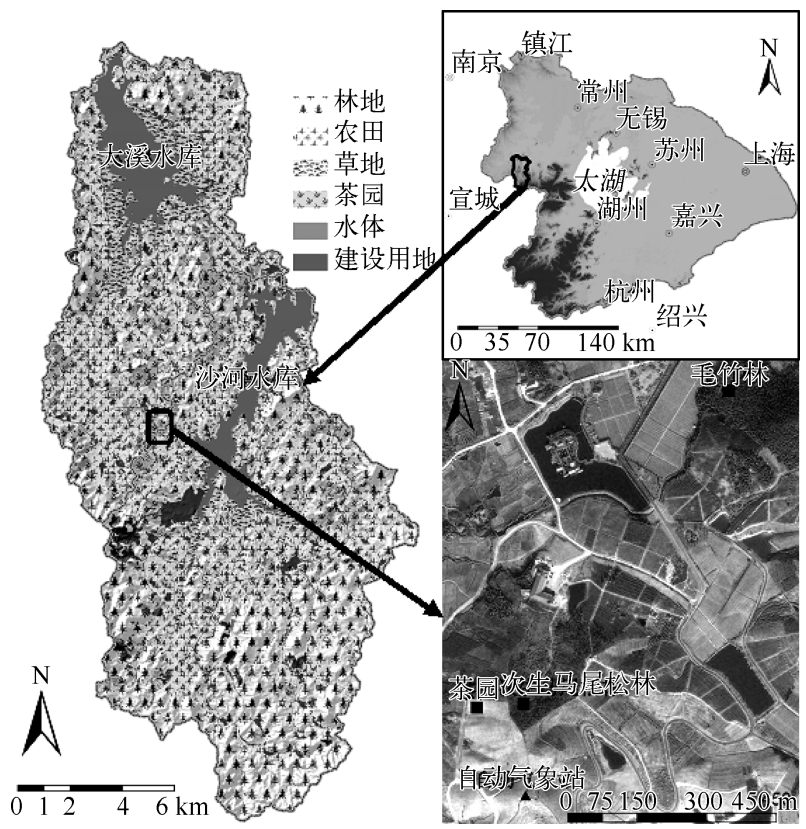

图 1 天目湖流域土地利用分布与径流小区布局

Fig. 1 Land use pattern of Tianmuhu Reservoir watershed and locations of experimental plots and automatic weather stations 
亚热带季风气候, 四季分明,多年平均气温 $15.8^{\circ} \mathrm{C}$, 年降水量 $1155.8 \mathrm{~mm}$, 受梅雨和台风雨共同影响, $3-9$ 月 降水量占全年降水量的 $76.0 \%$.

茶园主要是近年来丘陵山区农业综合开发过程中,通过成片清除整个山坡原有的次生马尾松林和毛竹 林后栽植茶树幼苗形成. 为了评估茶园扩张对流域氮流失的影响, 本研究选取茶园、次生马尾松林和毛竹林 3 种典型土地利用类型, 开展自然降雨条件下的原位径流小区实验. 本文为 2012 年实验的成果总结.

实验茶园为 2008 年种植的绿茶 (Camellia sinensis), 茶树等高栽种, 行间距为 $3 \mathrm{~m}$, 密度约为 30000 株 $/ \mathrm{hm}^{2} ; 2011$ 年 6 月- 2012 年 10 月进行实验,分别于 2011 年 11 月 20 日和 2012 年 2 月 27 日施肥 2 次,均为表土下约 $10 \mathrm{~cm}$ 处沟施天然高效有机肥 $336 \mathrm{~kg} \mathrm{~N} / \mathrm{hm}^{2} ; 2012$ 年 5 月 19 日修剪,茶树从高约 $85 \mathrm{~cm}$ 剪 至 $50 \mathrm{~cm}$, 随后逐渐恢复, 9 月底茶树株高达到 $90 \mathrm{~cm}$ 左右; 修剪后的枝叶平铺于行间, 枯枝叶厚度达 $4 \mathrm{~cm}$ 左 右, 逐渐腐烂, 至 9 月底基本分解完全. 次生马尾松林为自然用地类型, 林龄大于 20 年, 优势种为马尾松 $(P i-$ nus massoniana Lamb), 株高 $4 \mathrm{~m}$ 左右, 胸径约 $5 \mathrm{~cm}$, 松树密度约为 500 株 $/ \mathrm{hm}^{2}$; 伴生种以黎竹 (Acidosasa venusta) 为主, 株高 $1 \mathrm{~m}$, 灌丛生, 同时有多种灌木伴生; 枯落物层厚约 $1.5 \mathrm{~cm}$. 毛竹林也是自然用地类型, 林龄 大于 10 年, 优势种为毛竹 (Phyllostachys heterocycla cv. Pubescens), 株高 $8 \sim 10 \mathrm{~m}$, 胸径 $4 \mathrm{~cm}$ 左右, 立竹数约 为 3500 株 $/ \mathrm{hm}^{2}$; 伴生少量杉木 (Cunninghamia lanceolata), 株高约 $5 \mathrm{~m}$, 胸径 $5 \mathrm{~cm}$ 左右; 枯落物层厚约 $2 \mathrm{~cm}$.

\section{2 实验布设与样品分析}

径流小区分散布设在方圆 $1 \mathrm{~km}^{2}$ 的 3 个山坡上(图 1), 茶园小区位于茶园坡的中下部,次生马尾松林小 区位于次生马尾松林坡的中上部,毛竹林小区位于毛竹林坡中部,小区外围相同的用地类型至少延伸至 $5 \mathrm{~m}$ 以外. 径流小区坡长 $15 \mathrm{~m}$, 坡度 $15 \sim 25^{\circ}$, 用砖块和混泥土围隔而成, 混凝土墙露出地面 $20 \mathrm{~cm}$, 埋人地下 $10 \mathrm{~cm}$, 翻斗式流量仪 (精度 $0.25 \mathrm{~L}$ ) 和径流收集桶布设在小区下部的径流收集池中. 径流小区中部外侧约 $2 \mathrm{~m}$ 处的相同用地类型内埋设用来采集壤中流样品的陶瓷多孔杯 ${ }^{[14]}$ ( 孔隙直径 $<3 \mu \mathrm{m}$ ), 埋设深度为 $15 \mathrm{~cm}$. 径流小区基本特征见表 1 .

表 1 径流小区基本特征

Tab. 1 Physicochemical characteristics of experimental plots

\begin{tabular}{cccccccc}
\hline 样地类型 & 坡度 $^{\circ}$ & 面积 $/ \mathrm{m}^{2}$ & 土壤质地 & 有机质 $/(\mathrm{g} / \mathrm{kg})$ & 全氮 $/(\mathrm{g} / \mathrm{kg})$ & 铵态氮 $/(\mathrm{mg} / \mathrm{kg})$ & 硝态氮 $/(\mathrm{mg} / \mathrm{kg})$ \\
\hline 茶园 & 15.5 & 59 & 粉质壤土 & 54.60 & 1.32 & 0.63 & 2.64 \\
次生马尾松林 & 25.0 & 51 & 壤土 & 25.59 & 0.75 & 1.33 & 1.01 \\
毛竹林 & 16.4 & 95 & 壤土 & 42.14 & 1.15 & 2.10 & 1.74 \\
\hline
\end{tabular}

降雨结束后, 立即收集地表径流样品, 均匀混合桶内水样后收集 $500 \mathrm{ml}$ 样品, 并通过流量仪读数计算地 表径流量. 壤中流采样, 需在降雨初期预先将陶瓷多孔杯内气压抽至负压 $0.8 \mathrm{MPa}^{[15]}$, 降雨结束后抽取杯内 土壤溶液. 2012 年 6 月采集土壤样品, 实验期间连续监测径流小区内植被覆盖度变化状况 (图 2), 在邻近茶 园和次生马尾松林小区的山头布设自动气象站 (图 1), 为实验提供详细的降雨数据(图 3). 本实验共监测到 18 场产流明显的降雨事件, 累计降雨量约 $800 \mathrm{~mm}$, 收集茶园和次生马尾松林有效地表径流样品 18 次,毛竹 林 13 次; 壤中流样品 8 次.

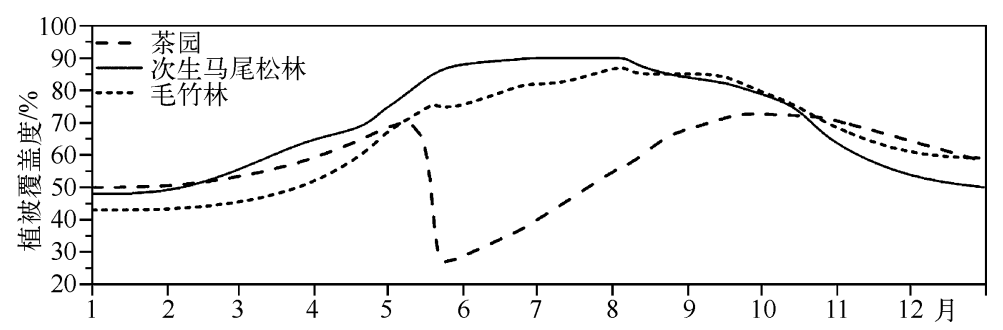

图 22012 年茶园、次生马尾松林和毛竹林植被覆盖度

Fig. 2 Vegetation coverage of tea plantation, secondary pine forest and bamboo forest in 2012 
样品分析在湖泊与环境国家重点实验室进行, 水样分析总氮 $(\mathrm{TN})$ 、溶解态总氮 $(\mathrm{DTN}) 、$ 硝态氮 $\left(\mathrm{NO}_{3}^{-}-\mathrm{N}\right)$ 和铵态氮 $\left(\mathrm{NH}_{4}^{+}-\mathrm{N}\right)$, 土壤样品分析粒度、有机质、全氮、铵态氮、硝态氮. 采集的水样冷藏保存, 3 天内送到实 验室进行化学分析, 原样用于分析 TN, 经 $0.45 \mu \mathrm{m}$ 的 Whatman GF/C 滤膜过滤后分析溶解态营养盐; TN 和 DTN 采用碱性过硫酸钾高温消解后紫外分光光度法测定 ${ }^{[16]}, \mathrm{NO}_{3}^{-}-\mathrm{N}$ 和 $\mathrm{NH}_{4}^{+}-\mathrm{N}$ 采用 Skalar 流动分析仪(荷 兰) 测定. $\mathrm{NO}_{3}^{-}-\mathrm{N}$ 和 $\mathrm{NH}_{4}^{+}-\mathrm{N}$ 之和为溶解性无机氮 (DIN), DTN 和 DIN 之差为溶解性有机氮 (DON). 新鲜土 壤经 $1 \mathrm{~mol} / \mathrm{L}$ 的 $\mathrm{KCl}$ 溶液浸提后, 采用 Skalar 流动分析仪 (荷兰) 测定铵态氮和硝态氮; 风干后, 采用 LS230 激光粒度仪 (美国) 测定粒度 ${ }^{[17]}$, 过 100 目笁网后, 采用 EA3000 元素分析仪测定全氮 ( TN) (方法参见 ISO 13878-1998) 和有机碳( OC) (方法参见 ISO 10694-1995), 有机质( OM) 基于 OC 换算获取.

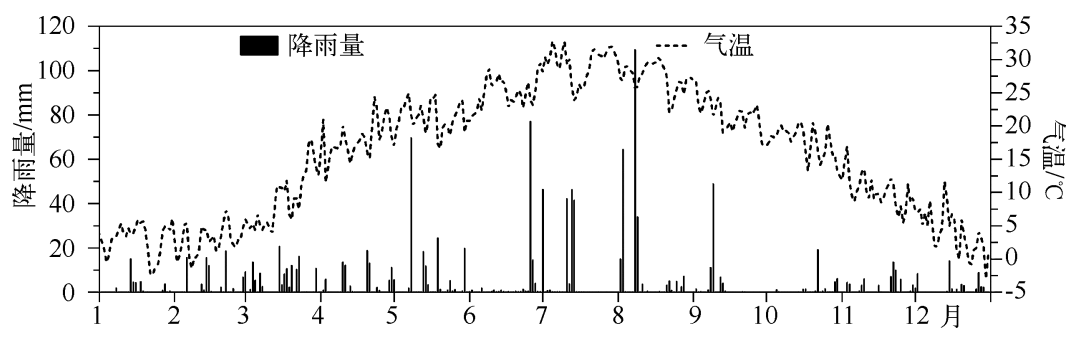

图 32012 年实验区降雨量与气温

Fig. 3 Rainfall and air temperature of the experimental area in 2012

\section{2 结果与分析}

\section{1 不同土地利用类型地表径流氮流失特征}

2.1 .1 不同土地利用类型地表径流产流特征 茶园、次生马尾松林和毛竹林地表径流产流均较少,但产流量 差异较大. 监测降雨事件, 3 种用地类型累计地表径流深依次为 $1.75 、 4.16$ 和 $11.91 \mathrm{~mm}$, 各用地类型径流系 数 (即径流深与降雨量的比值) ${ }^{[18]}$ 均未超过 0.03 . 监测降雨事件总径流系数, 毛竹林最大, 为 0.017 , 分别是 茶园和次生马尾松林的 7.9 和 3.3 倍. 不同用地类型地表径流系数表现出不同的时间变化规律: 茶园 5-9 月径流系数持续较低, 明显低于 $3 、 4$ 月; 尽管次生马尾松林 3 月份径流系数呈现出明显的降低趋势, 但次生 马尾松林和毛竹林 5-9 月份径流系数变化不大.

各用地类型监测降雨事件的地表径流深与降雨量均存在较好的相关性, 线性拟合优度较高. 拟合出的 直线斜率, 茶园最低, 仅为 0.0015 , 毛竹林最高, 为 0.0130 (图 4). 该斜率在一定程度上可以体现地表的下渗 能力 ${ }^{[19]}$, 茶园地表频繁受到施肥、除草等扰动, 下渗较强; 而次生马尾松林和毛竹林均为自然用地类型, 下渗 相对较弱.
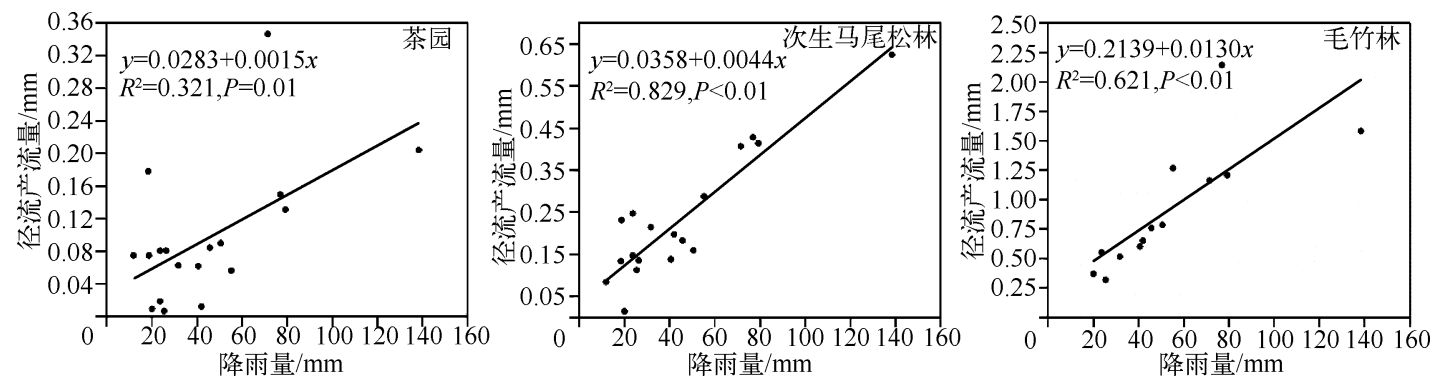

图 4 不同用地类型地表径流产流量与降雨量关系

Fig. 4 Relationship between surface runoff depth and rainfall from different land use patterns

2.1 .2 不同土地利用类型地表径流氮浓度特征 不同土地利用类型各监测降雨事件地表径流氮浓度如图 5 . 茶园地表径流 TN 平均浓度为 $11.25 \mathrm{mg} / \mathrm{L}$, 显著高于次生马尾松林与毛竹林 ( 0.05 显著水平), 分别是二 
者的 4.0 和 3.1 倍. 各用地类型地表径流 TN 浓度年内差异均较大,且不同用地类型表现出的规律不完全一 致. 各用地类型均表现出: 前期无降雨时间较长 时,地表径流 TN 浓度相对较高, 连续降雨过程 中,浓度呈现降低的趋势. 此外, 茶园还表现出 5-9月份地表径流 TN 浓度明显高于 3 月份的 特征,而次生马尾松林和毛竹林各月径流浓度 无明显差异 (表 2).

茶园、次生马尾松林和毛竹林地表径流 TN 均以溶解态氮为主,分别占 $84 \% 、 79 \%$ 和 73\% ; 地表径流 TN 中溶解态所占比例, 茶园显著高于 毛竹林, 而次生马尾松林与其他 2 种用地类型的 差异不显著 (0.05 显著水平). DIN 为地表径流 $\mathrm{TN}$ 的重要组成部分, 茶园和次生马尾松林 DIN 所占的比例分别高达 $63 \%$ 和 $54 \%$,均显著高于

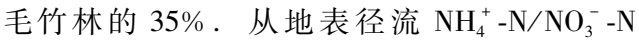
看, 茶园 $\mathrm{NH}_{4}^{+}-\mathrm{N} 、 \mathrm{NO}_{3}^{-}-\mathrm{N}$ 浓度相当, 次生马尾松 林 $\mathrm{NO}_{3}^{-}-\mathrm{N}$ 浓度明显高于 $\mathrm{NH}_{4}^{+}-\mathrm{N}$, 毛竹林 $\mathrm{NH}_{4}^{+}-\mathrm{N}$ 浓度明显高于 $\mathrm{NO}_{3}^{-}-\mathrm{N}$ (图 5).

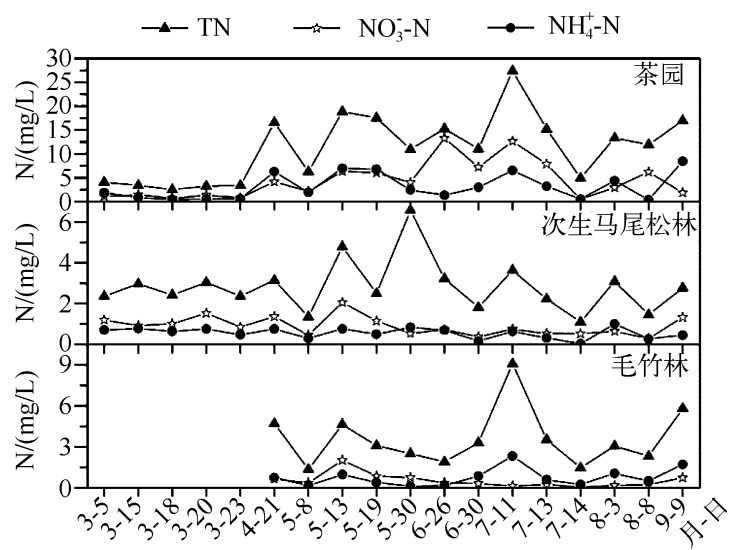

图 5 不同用地类型地表径流

$\mathrm{TN} 、 \mathrm{NO}_{3}^{-}-\mathrm{N}$ 和 $\mathrm{NH}_{4}^{+}-\mathrm{N}$ 浓度

Fig. 5 Nitrogen concentration in surface runoff from tea plantation, secondary pine forest and bamboo forest

表 2 不同用地类型地表径流氮浓度特征 ${ }^{*}$

Tab. 2 Nitrogen concentration characteristics in surface runoff from tea plantation, secondary pine forest and bamboo forest

\begin{tabular}{|c|c|c|c|c|c|c|c|}
\hline 用地类型 & $\begin{array}{c}\mathrm{TN} / \\
(\mathrm{mg} / \mathrm{L})\end{array}$ & $\begin{array}{l}\mathrm{NO}_{3}^{-}-\mathrm{N} / \\
(\mathrm{mg} / \mathrm{L})\end{array}$ & $\begin{array}{l}\mathrm{NH}_{4}^{+}-\mathrm{N} / \\
(\mathrm{mg} / \mathrm{L})\end{array}$ & $\begin{array}{l}\text { DON/ } \\
(\mathrm{mg} / \mathrm{L})\end{array}$ & $\mathrm{DTN} / \mathrm{TN}$ & DIN/TN & $\mathrm{NH}_{4}^{+}-\mathrm{N} / \mathrm{NO}_{3}^{-}-\mathrm{N}$ \\
\hline 茶园 & $\begin{array}{c}11.25 \pm 7.01 \\
(2.50 \sim 27.37)\end{array}$ & $\begin{array}{c}4.46 \pm 3.92 \\
(0.52 \sim 13.27)\end{array}$ & $\begin{array}{c}3.12 \pm 2.72 \\
(0.38 \sim 8.43)\end{array}$ & $\begin{array}{c}2.43 \pm 1.99 \\
(0.31 \sim 7.43)\end{array}$ & $0.84 \pm 0.12$ & $0.63 \pm 0.17$ & $7 \quad 1.00 \pm 1.01$ \\
\hline 次生马尾松林 & $\begin{array}{c}2.83 \pm 1.28 \\
(1.11 \sim 6.58)\end{array}$ & $\begin{array}{c}0.91 \pm 0.46 \\
(0.30 \sim 2.06)\end{array}$ & $\begin{array}{c}0.57 \pm 0.26 \\
(0.04 \sim 1.01)\end{array}$ & $\begin{array}{c}0.72 \pm 0.44 \\
(0.25 \sim 1.63)\end{array}$ & $0.79 \pm 0.14$ & $0.54 \pm 0.16$ & $\begin{array}{ll}6 & 0.69 \pm 0.39\end{array}$ \\
\hline 毛竹林 & $\begin{array}{c}3.60 \pm 2.11 \\
(1.35 \sim 9.10)\end{array}$ & $\begin{array}{c}0.53 \pm 0.52 \\
(0.05 \sim 2.02)\end{array}$ & $\begin{array}{c}0.75 \pm 0.65 \\
(0.11 \sim 2.32)\end{array}$ & $\begin{array}{c}1.33 \pm 1.06 \\
(0.56 \sim 4.39)\end{array}$ & $0.73 \pm 0.08$ & $0.35 \pm 0.11$ & $13.22 \pm 4.64$ \\
\hline
\end{tabular}

* 均值 \pm 标准差 (最小值 最大值).

\section{2 不同土地利用类型壤中流氮流失特征}

2.2.1 不同土地利用类型壤中流氮浓度特征 不同土地利用类型各监测降雨事件壤中流氮浓度如图 6. 茶 园壤中流 TN 平均浓度高达 $27.16 \mathrm{mg} / \mathrm{L}$, 显著高于次生马尾松林和毛竹林, 分别是二者的 7.6 和 25.7 倍. 各 用地类型不同降雨事件间壤中流 TN 浓度差异均较大,且不同用地类型间表现出不同的规律. 茶园前期无降 雨时间较长时浓度相对较低、连续降雨过程中浓度逐渐升高, 而次生马尾松林和毛竹林则表现出相反的规 律(表3).

茶园和次生马尾松林壤中流 TN 形态构成上也与毛竹林存在显著差异,而茶园和次生马尾松林之间差 异不显著 (0.05 显著水平). 茶园和次生马尾松林壤中流 TN 均以 DIN 为主, DIN 所占比例均在 $76 \%$ 左右,且 均以 $\mathrm{NO}_{3}^{-}-\mathrm{N}$ 为主, $\mathrm{NH}_{4}^{+}-\mathrm{N} / \mathrm{NO}_{3}^{-}-\mathrm{N}$ 分别仅为 0.005 和 0.022 ; 毛竹林以 DON 为主, DIN 所占比例仅为 $31 \%$, 显著低于茶园和次生马尾松林, 且以 $\mathrm{NH}_{4}^{+}-\mathrm{N}$ 为主, 其 $\mathrm{NH}_{4}^{+}-\mathrm{N} / \mathrm{NO}_{3}^{-}-\mathrm{N}$ 高达 9.638 ,显著高于其他 2 种用地类 型 $(0.05$ 显著水平).

2.2 .2 典型土地利用类型地表径流与壤中流氮浓度差异 尽管各用地类型地表径流与壤中流 TN 浓度均表 现出较大差异,但不同用地类型间差异表现不同. 茶园壤中流 TN 平均浓度显著高于地表径流,前者是后者 


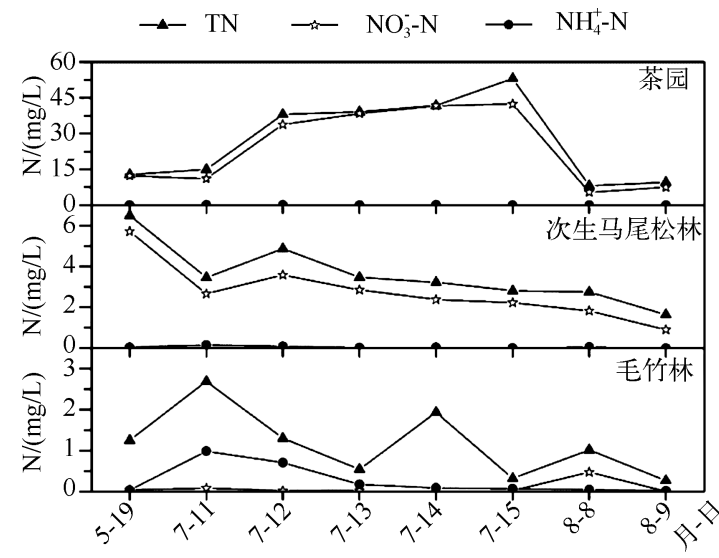

图 6 不同用地类型壤中流 $\mathrm{TN} 、 \mathrm{NO}_{3}^{-}-\mathrm{N}$ 和 $\mathrm{NH}_{4}^{+}-\mathrm{N}$ 浓度

Fig. 6 Nitrogen concentration in subsurface runoff from tea plantation, secondary pine forest and bamboo forest
的 2.4 倍; 次生马尾松林壤中流 TN 平均浓度略 高于地表径流, 为其 1.3 倍; 与茶园和次生马尾 松林不同,毛竹林壤中流 TN 浓度显著低于地表 径流( 0.05 显著水平), 前者仅为后者的 $29.4 \%$.

各用地类型地表径流与壤中流 $\mathrm{NO}_{3}^{-}-\mathrm{N}$ 浓 度差异均非常显著 (0.05 显著水平), 规律与 $\mathrm{TN}$ 基本一致, 也表现为茶园和次生马尾松林 壤中流 $\mathrm{NO}_{3}^{-}-\mathrm{N}$ 浓度高于地表径流, 而毛竹林 地表径流浓度高于壤中流. 至于 $\mathrm{NH}_{4}^{+}-\mathrm{N}$ 浓度, 茶园和次生马尾松林地表径流显著高于壤中 流, 尽管毛竹林也表现为地表径流浓度高于壤 中流, 但差异不显著 (0.05 显著水平). DIN 所 占的比例, 茶园和次生马尾松林地表径流与壤 中流规律基本一致, TN 均以 DIN 为主, 而毛竹 林地表径流与壤中流 TN 均以 DON 为主, 且各 用地类型均表现为壤中流 DIN 所占的比例高

于地表径流.

表 3 不同用地类型壤中流氮浓度特征

Tab. 3 Nitrogen concentration characteristics in subsurface runoff from tea plantation, secondary pine forest and bamboo forest

\begin{tabular}{|c|c|c|c|c|c|c|}
\hline 用地类型 & $\begin{array}{c}\mathrm{TN} / \\
(\mathrm{mg} / \mathrm{L})\end{array}$ & $\begin{array}{l}\mathrm{NO}_{3}^{-}-\mathrm{N} / \\
(\mathrm{mg} / \mathrm{L})\end{array}$ & $\begin{array}{l}\mathrm{NH}_{4}^{+}-\mathrm{N} / \\
(\mathrm{mg} / \mathrm{L})\end{array}$ & $\begin{array}{l}\text { DON/ } \\
(\mathrm{mg} / \mathrm{L})\end{array}$ & $\mathrm{DIN} / \mathrm{TN}$ & $\mathrm{NH}_{4}^{+}-\mathrm{N} / \mathrm{NO}_{3}^{-}-\mathrm{N}$ \\
\hline 茶园 & $\begin{array}{l}27.16 \pm 17.59 \\
(8.11 \sim 53.04)\end{array}$ & $\begin{array}{c}24.05 \pm 16.36 \\
(5.41 \sim 42.37)\end{array}$ & $\begin{array}{c}0.067 \pm 0.017 \\
(0.039 \sim 0.094)\end{array}$ & $\begin{array}{c}3.05 \pm 3.42 \\
(0.48 \sim 10.61)\end{array}$ & $0.86 \pm 0.12$ & $0.005 \pm 0.003$ \\
\hline $\begin{array}{l}\text { 次生马 } \\
\text { 尾松林 }\end{array}$ & $\begin{array}{c}3.59 \pm 1.48 \\
(1.64 \sim 6.49)\end{array}$ & $\begin{array}{c}2.77 \pm 1.42 \\
(0.90 \sim 5.72)\end{array}$ & $\begin{array}{c}0.059 \pm 0.047 \\
(0.011 \sim 0.159)\end{array}$ & $\begin{array}{c}0.76 \pm 0.20 \\
(0.57 \sim 1.19)\end{array}$ & $0.76 \pm 0.10$ & $0.022 \pm 0.017$ \\
\hline 毛竹林 & $\begin{array}{c}1.06 \pm 0.84 \\
(1.35 \sim 9.10)\end{array}$ & $\begin{array}{c}0.09 \pm 0.17 \\
(0.01 \sim 0.47)\end{array}$ & $\begin{array}{c}0.290 \pm 0.391 \\
(0.018 \sim 0.984)\end{array}$ & $\begin{array}{c}0.67 \pm 0.53 \\
(0.23 \sim 1.63)\end{array}$ & $0.32 \pm 0.19$ & $9.638 \pm 13.935$ \\
\hline
\end{tabular}

* 均值 \pm 标准差 (最小值 最大值).

\section{3 不同土地利用类型径流氮流失量估算}

各用地类型全年坡面径流产流总量, 根据 2012 年径流小区实测数据拟合出来的线性模型计算获取 (图 4). 壤中流流量难以实测, 通过小流域总径流量扣除坡面地表径流量获取. 本实验未开展小流域径流监测, 参考同处于太湖流域湖西丘陵区的宜兴梅林小流域实测参数, 总径流系数统一取 0.305 进行估算 ${ }^{[20]}$. 实验 用地类型 2012 年径流氮流失量估算结果如表 4.

表 42012 年不同用地类型径流 TN 流失特征

Tab. 4 Nitrogen loss via runoff from tea plantation, secondary pine forest and bamboo forest in 2012

\begin{tabular}{|c|c|c|c|c|c|c|c|}
\hline \multirow{2}{*}{ 用地类型 } & \multicolumn{2}{|c|}{ 径流深/mm } & \multicolumn{2}{|c|}{$\mathrm{TN}$ 浓度/( mg/L) } & \multicolumn{3}{|c|}{$\mathrm{TN}$ 流失量/ $\left(\mathrm{kg} / \mathrm{hm}^{2}\right)$} \\
\hline & 地表径流 & 壤中流 & 地表径流 & 壤中流 & 地表径流 & 壤中流 & 合计 \\
\hline 茶园 & 2.53 & 378.42 & 11.25 & 27.16 & 0.28 & 102.79 & 103.08 \\
\hline 次生马尾松林 & 5.03 & 375.91 & 2.83 & 3.59 & 0.14 & 13.50 & 13.65 \\
\hline 毛竹林 & 16.45 & 364.49 & 3.60 & 1.06 & 0.59 & 3.85 & 4.44 \\
\hline
\end{tabular}

各用地类型径流组成均以壤中流为主, 壤中流均占径流总量的 $95 \%$ 以上. 不同用地类型 $\mathrm{TN}$ 流失量差异 
明显, 茶园最大, 毛竹林最小, 茶园流失强度高达 $103.08 \mathrm{~kg} /\left(\mathrm{hm}^{2} \cdot \mathrm{a}\right)$, 分别是次生马尾松林和毛竹林的 7.6 和 23.2 倍. 各用地类型径流 TN 流失均以壤中流为主, 茶园、次生马尾松林和毛竹林经壤中流流失的 TN 占 各自径流 TN 流失总量的比例分别高达 $99.7 \%$ 、99.0\% 和 $86.7 \%$.

\section{3 讨论}

径流氮流失过程实质是表层土壤与降雨、径流的相互作用过程, 主要由径流冲刷、淋洗土壤氮素引 起 ${ }^{[21]}$, 受自然因素和人为因素的影响 ${ }^{[22]}$. 不同用地类型径流氮流失特征的差异, 本质是土地利用类型所反 映的下垫面生态特征和人类活动因子组合对土壤氮含量和径流特征影响的差异. 该组合的构成要素主要包 括土壤氮含量、施肥状况、植被生长吸收状况、植被盖度、地表枯枝落叶层、地形、土壤粒度等. 不同用地类型 枯枝落叶层和土壤粒度等下垫面状况的差异, 导致用地类型间地表径流和壤中流流量的差异, 并通过表土 氮含量和径流-土壤作用强度的差异, 影响地表径流和壤中流氮浓度, 最终使得不同用地类型径流氮流失量 及流失途径存在较大的差异.

\section{1 不同用地类型坡面径流氮流失差异明显的原因初探}

植被冠层、底层枯落物的拦截能力和表土的人渗能力决定着地表产流状况. Girmay 等 ${ }^{[19]}$ 指出, 当植被 覆盖度超过 $65 \%$ 72\% 时,地表径流会维持在一个低产流量水平. 本研究中, 各用地类型径流系数均未超过 0.03 , 可能原因如下: 毛竹林和次生马尾松林雨季期间植被覆盖度均超过了 70\%（图 2）, 必然导致地表径流 产流较少; 而茶园修剪后行间存在厚约 $4 \mathrm{~cm}$ 的枯枝叶层, 覆盖高达 $40 \%$ 以上的行间区域, 也有效减少了地 表径流. 毛竹林径流系数分别为茶园和次生马尾松林的 7.9 和 3.3 倍, 与毛竹林表土有机质含量相对较低, 地表对雨水的吸持能力较弱有关; 此外, 茶园等高耕作,径流拦截能力较强, 且茶园表土频繁松动导致下渗 能力较强,也是重要原因 ${ }^{[23]}$.

坡面径流氮素主要来源于土壤表层氮素的冲刷剥离、溶出和土壤剖面氮素的淋溶 ${ }^{[24]}$. 施肥量与植被生 长吸收状况, 主要通过影响表土氮素的输人、输出量而影响土壤表层氮素的盈余/亏损状况 ${ }^{[25]}$, 进而改变土 壤氮含量. 茶园、次生马尾松林和马竹林地表径流和壤中流 TN 浓度高低关系与各用地类型表土全氮含量相 对一致,体现了土壤氮含量对径流氮浓度的重要影响. 植被覆盖状况、枯枝落叶层和土壤粒度均通过减少径 流和减弱冲刷来影响径流氮流失强度. 植被通过冠层截留削减到达地表的净雨量, 枯枝落叶层进一步吸持 雨水, 共同减少产流量; 同时植被冠层减缓雨滴降落速度、枯枝落叶层避免雨水直接击打地表, 均能减少雨 滴对地表的㳚蚀强度 ${ }^{[26]}$; 此外枯枝落叶层增加地表粗糙度, 减缓径流流速, 从而降低冲刷强度 ${ }^{[27]}$; 土壤粒度 影响土壤的水力传导特性,砂粒比重越高, 下渗能力越强,地表径流产流量越少,径流冲刷能力越弱. 土壤表 层氮含量越低、径流冲刷能力越弱, 径流氮流失的风险越小. 地表对降雨和径流的拦蓄和下渗作用, 不仅影 响径流量, 还影响着径流在地表径流和壤中流的分配以及与土壤的作用强度 ${ }^{[21]}$.

地表径流中的氮素通过冲刷和淋溶等途径进人径流,而壤中流中的氮素主要通过淋洗进人. 带正电荷 的铵根离子易于被土壤胶体吸附, 难以淋失, 主要靠地表径流的冲刷进人水体, 因而壤中流 $\mathrm{NH}_{4}^{+}-\mathrm{N}$ 浓度明 显低于地表径流; 而带负电荷的硝酸根离子不易被吸附, 极易淋失 ${ }^{[28]}$, 因而地表径流与壤中流中均大量存 在, 且壤中流 $\mathrm{NO}_{3}^{-}-\mathrm{N}$ 浓度相对较高. 茶园土壤硝态氮含量远高于铵态氮 (表 1), 而硝态氮的流失以壤中流为 主 ${ }^{[29]}$, 因此茶园壤中流氮浓度高于地表径流. 鉴于毛竹林径流 TN 浓度远低于茶园, 且其壤中流 TN 浓度明 显低于地表径流, 可以考虑在茶园坡脚构建毛竹林隔离带, 通过毛竹林土壤强大的吸附能力, 实现茶园径流 氮的原位拦截.

\section{2 不同用地类型坡面径流氮流失呈现时间变化特征的原因剖析}

地表径流系数表现出的时间变化规律, 是对降雨特征以及植被覆盖度等下垫面条件随时间变化的综合 响应; 不同用地类型因植被类型、耕作活动差异引起的下垫面差异, 是不同用地类型坡面径流氮流失时间变 化规律不同的根本原因. 茶园 3、4 月径流系数明显高于 5-9 月,且 5-9 月茶园径流系数持续较低,与茶园 5 月修剪后,枯枝叶平铺于行间,至 9 月底才基本分解完全,该时段内茶园地表吸持雨水和拦截径流能力更 强有关. 次生马尾松林 3 月份径流系数呈现出明显的降低趋势, 与 3 月份枝叶迅速生长、植被覆盖度增加, 拦 截降雨能力增强有关. 次生马尾松林和毛竹林 5-9 月份径流系数变化不大, 与本时段内二者植被覆盖度一 直很高, 均超过了 $72 \%$ 的阈值有关 ${ }^{[19]}$. 
前期降雨、产流状况对表土层的可流失氮素含量以及径流冲刷、淋溶能力存在较大影响 ${ }^{[30]}$, 降雨的时间 分布不均引起不同降雨事件前期降雨、产流状况不同, 从而导致径流氮含量表现出一定的时间变化特征. 实 验用地类型均表现出的前期无降雨时间较长时地表径流浓度较高、连续降雨时浓度趋降的规律, 究其原因: 一方面由于连续降雨期间地表遭受频繁冲刷, 土壤表层可溶人径流的氮减少; 另一方面因为连续降雨期间 土壤含水量较高, 土壤抗冲刷能力相对较强 ${ }^{[31]}$. 前期无降雨时间较长时, 茶园壤中流氮浓度相对较低、连续 降雨过程中浓度逐渐升高, 可能与茶园表土硝态氮含量相对较高, 连续降雨过程中, 土壤含水量高, 表土硝 态氮逐渐向下迁移有关 ${ }^{[30]}$; 而次生马尾松林和毛竹林则表现出相反的规律, 可能与其表土硝态氮含量相对 茶园较低有关. 在此仅针对不同用地类型壤中流氮含量对降雨状况响应差异的可能原因进行了推理, 后期 需要进一步开展土壤的吸附一解吸动力学实验加以验证.

不同用地类型产流状况的时间变化规律的差异也将引起不同用地类型径流冲刷、淋溶状况不同,进而 导致不同用地类型间地表径流氮浓度时间变化规律存在明显差异. 茶园表现出 5-9 月份地表径流 TN 浓度 明显高于 3 月份的特征, 与茶园修剪后, 枯枝叶平铺于行间, 5-9 月地表径流均淋洗过枯枝落叶导致浓度升 高有关; 而次生马尾松林和毛竹林各月无明显差异, 与实验期间这两种用地类型产流状况和氮流失条件无 明显变化有关.

\section{3 相关区域坡面氮流失量比较}

茶园氮流失强度高达 $103.08 \mathrm{~kg} /\left(\mathrm{hm}^{2} \cdot \mathrm{a}\right)$, 与太湖流域稻麦轮作耕地的流失量 $\left(55.3 \sim 93.1 \mathrm{~kg} /\left(\mathrm{hm}^{2} \cdot \mathrm{a}\right)\right)$ 接 近 ${ }^{[32]}$, 流失量高达年度施肥总量的 $30.7 \%$ 左右, 可见当前茶园仍存在较大的减量施肥空间. 本研究茶园径 流 TN 流失量高于湖南桃源 ${ }^{[9]}$ 、安徽㪘县 ${ }^{[10]}$ 和江苏武进 ${ }^{[11]}$ 的茶园研究结果, 可能与全面考虑了地表径流和 壤中流流失有关. 次生马尾松林径流 TN 流失量大于毛竹林, 与韩芗等 ${ }^{[25]}$ 认为竹林较马尾松林更有利于水 环境保护的观点基本一致. 从流失途径看, 各用地类型径流 TN 流失均以壤中流为主, 茶园、次生马尾松林和 毛竹林分别 $99.7 \% 、 99.0 \%$ 和 $86.7 \%$, 与刘泉等 ${ }^{[13]}$ 在汉江水源区坡地研究中, 壤中流携带的 $\mathrm{NO}_{3}^{-}-\mathrm{N}$ 流失量 占径流小区硝态氮流失量的 $87.81 \% \sim 98.99 \%$ 基本一致.

壤中流流量估算时, 尽管径流系数参考同处于太湖流域湖西丘陵区的宜兴梅林小流域的实测参数, 总 径流量基本接近实际情况, 但该壤中流可能包含一定的地下水补给量, 而本研究未测定地下水氮含量, 没有 考虑土壤溶液垂向迁移过程中的浓度下降 ${ }^{[33]}$, 可能在一定程度上高估了壤中流氮流失量; 此外, 估算总径流 时, 不同用地类型采用了相同的径流系数, 与实际不符, 也增加了本研究结果的不确定性. 后续研究中, 需要 结合坡面尺度营养盐输移机理模型加以深化.

\section{4 结论}

茶园地表径流和壤中流 TN 浓度分别为 11.25 和 $27.16 \mathrm{mg} / \mathrm{L}$, 均显著高于次生马尾松林与毛竹林, 分别 为次生马尾松林的 4.0 和 7.6 倍、毛竹林的 3.1 和 25.7 倍. 地表径流 TN 均以溶解态为主, DIN 为重要组成 部分; 且均前期无降雨时间较长时浓度较高, 连续降雨过程中浓度逐渐降低. 壤中流 TN, 茶园和次生马尾松 林以 DIN (尤其是 $\mathrm{NO}_{3}^{-}-\mathrm{N}$ ) 为主, 毛竹林以 DON 为主; 茶园前期无降雨时间较长时浓度相对较低、连续降雨 过程中浓度逐渐升高, 而次生马尾松林和毛竹林则表现出相反的规律; 茶园和次生马尾松林壤中流 TN 浓度 明显高于地表径流,而毛竹林规律正好相反.

丘陵山区各实验用地类型小区尺度地表径流产流均极少, 径流系数均小于 0.03 , 壤中流是其径流的主 要组成形式. 茶园氮流失强度高达 $103.08 \mathrm{~kg} /\left(\mathrm{hm}^{2} \cdot \mathrm{a}\right)$, 分别是次生马尾松林和毛竹林的 7.6 和 23.2 倍. 茶园扩张加剧了丘陵山区的氮素流失, 主要体现在地表径流和壤中流氮浓度升高上, 连续降雨期间表现得 更为突出; 壤中流是丘陵山区氮流失的主要途径, 茶园、次生马尾松林和毛竹林壤中流 TN 输出量占各自总 流失量的比例分别高达 $99.7 \%$ 、99.0\% 和 $86.7 \%$.

防治茶园径流氮流失必须重点关注壤中流输出, 在减量施肥的基础上, 可以考虑通过在茶园坡脚构建 毛竹林生态缓冲带和小流域出口处布设塘坝相结合的原位拦截措施实现流域氮流失的综合防控.

致谢: 天目湖生态农业有限公司的陈建华在野外样品采集, 中国科学院南京地理与湖泊研究所的任理、张成 英和顾钊在室内水样分析方面提供了大量帮助,在此表示衰心感谢! 


\section{5 参考文献}

[ 1 ] 水利部太湖流域管理局. 太湖健康状况报告 2011.上海,2012.

[2] 李恒鹏,杨桂山, 黄文钰等. 太湖上游地区面源污染氮素人湖量模拟研究. 土壤学报,2007,44(6):1063-1069.

[ 3 ] Hirono Y, Watanabe I, Nonaka K. Trends in water quality around an intensive tea-growing area in Shizuoka, Japan. Soil Science and Plant Nutrition, 2009, 55 : 783-792.

[ 4 ] Nagumo T, Yosoi T, Aridomi A. Impact of agricultural land use on $\mathrm{N}$ and P concentration in forest-dominated tea-cultivating watersheds. Soil Science and Plant Nutrition, 2012, 58: 121-134.

[ 5 ] 刘宗岸,杨京平,杨正超等. 苕溪流域茶园不同种植模式下地表径流氮磷流失特征. 水土保持学报,2012,26(2): 29-32,44.

[ 6 ] 王京文,孙吉林,张奇春等. 西湖名胜区茶园地表径流水的氮磷流失研究. 浙江农业学报,2012,24(4):676-679.

[ 7 ] GB/T 3838-2002. 中华人民共和国国家标准地表水环境质量标准. 北京: 中国环境科学出版社,2002.

[ 8 ] Kothyari BP, Verma PK, Joshi BK et al. Rainfall-runoff-soil and nutrient loss relationships for plot size areas of Bhetagad watershed in Central Himalaya, India. Journal of Hydrology, 2004 ,293 : 137-150.

[9] 马军福,谢小立. 坡地不同垫面产流及物质联动研究. 水土保持学报,2010,24(1):78-81.

[10］马友华,谢昕云,马中文等. 安徽省园地氮磷径流流失. 水土保持学报,2012,26(3):12-17.

[11］徐 欣,席运官,陈瑞冰等.太湖流域坡地茶园径流流失规律. 生态与农村环境学报,2010,26(4):381-385.

[12] Tanaka TI, Hhirata T. Groundwater chemistry near a tea plantation in the center of Shizuoka prefecture, Japan. Annu J Hydraulic Eng, 2001, 45: 355-360.

[13] 刘 泉,李占斌,李 鹏等. 汉江水源区自然降雨过程下坡地壤中流对硝态氮流失的影响. 水土保持学报,2012,26 (5) : $: 1-5,10$.

[14] Grossmann J, Udluft P. The extraction of soil water by the suction-cup method: a review. Journal of Soil Science, 1991, 42(1): 83-93.

[15] 褚利平, 王克勤, 宋泽芬等. 烤烟坡耕地壤中流氮、磷浓度的动态特征. 农业环境科学学报, 2010, 29(7): 1346-1354.

[16] 国家环境保护总局. 水和废水监测分析方法:第 4 版. 北京: 中国环境科学出版社,2002:246-248.

[17］张甘霖,龚子同.土壤调查实验室分析方法:第 1 版. 北京:科学出版社,2012:16-19.

[18］延军平,汪西莉,孙 虎等. 陕、甘干旱地区不同时段地表径流递减率的分析. 地理科学, 1999,(6):532-535.

[19] Girmay G, Singh BR, Nyssen J et al. Runoff and sediment-associated nutrient losses under different land uses in Tigray, Northern Ethiopia. Journal of Hydrology, 2009, 376: 70-80.

[20] 李瑞玲,张永春,曾 远等. 太湖流域丘陵地区暴雨条件下农田氮素随地表径流迁移特征. 农业环境科学学报, 2009,28 (6) : $1185-1190$.

[21］张兴昌,邵明安. 坡地土壤氮素与降雨、径流的相互作用机理及模型. 地理科学进展,2000,19(2):128-135.

[22］杨丽霞,杨桂山,苑韶峰等. 影响土壤氮素径流流失的因素探析. 中国生态农业学报,2007,15(6):190-194.

[23] 吴发启,赵西宁,崔卫芳. 坡耕地耕作管理措施对降雨人渗的影响. 水土保持学报,2003,(3):115-117.

[24] 王全九,沈 晋,王文焰等. 降雨条件下黄土坡面溶质随地表径流迁移实验研究. 水土保持学报, 1993,7(1):1117,52 .

[25] 韩 莹, 李恒鹏, 聂小飞等. 太湖上游低山丘陵地区不同用地类型氮、磷收支平衡特征. 湖泊科学, 2012,24(6): 829-837.

[26] 王晓燕,王静怡,欧 洋等. 坡面小区土壤-径流-泥沙中磷素流失特征分析. 水土保持学报,2008,22(2):1-5.

[27] 张洪江,程金花,余新晓等. 贡嘎山冷杉纯林枯落物储量及其持水特性. 林业科学,2003,39(5):147-151.

[28］王德建,林静慧,夏立忠. 太湖地区稻麦轮作农田氮素淋洗特点. 中国生态农业学报,2001,9(1):26-28.

[29] 朱 波,汪 涛,况福虹等. 紫色土坡耕地硝酸盐淋失特征. 环境科学学报,2008,(3):525-533.

[30] 王 辉, 王全九, 邵明安. 前期土壤含水量对黄土坡面氮磷流失的影响及最优含水量的确定. 环境科学学报,2008, (8) : :1571-1578.

[31] 徐泰平,朱 波,汪 涛等. 不同降雨侵蚀力条件下紫色土坡耕地的养分流失. 水土保持研究, 2006, (6):139-141.

[32] Zhao X, Zhou Y, Min J et al. Nitrogen runoff dominates water nitrogen pollution from rice-wheat rotation in the Taihu Lake region of China. Agriculture, Ecosystems \& Environment, 2012,156:1-11.

[33] Tian Y, Yin B, Yang L et al. Nitrogen runoff and leaching losses during rice-wheat rotations in taihu lake region, China. Pedosphere, 2007,17 (4) ):445-456. 